\title{
Regional University in the EdTech Market of Educational Services
}

\author{
Andreyanova I.V. \\ Pskov State University, \\ Pskov, Russia, \\ jurist-i@mail.ru \\ Serebryakova A.A. \\ Pskov State University, \\ Pskov, Russia
}

\author{
Kuklev S.E \\ Pskov State University, \\ Pskov, Russia \\ Serova O.A. \\ Pskov State University, \\ Pskov, Russia
}

\begin{abstract}
The article analyzes the position of regional universities in the context of heightened competition in the educational services market. Regional universities were seen as a base for innovative changes in one area or another. However, with the advent of new educational technologies (EdTech), universities are losing their leading positions. The article defines the necessary conditions for changing the positioning of universities. The factors that hinder the inclusion of universities in the sphere of new educational technologies are identified. The promising directions and requirements for the transformation of universities are determined, taking into account the principles of the EdTech market.
\end{abstract}

Keywords-market of educational services, regional university, EdTech, innovative development

\section{INTRODUCTION}

The new technological reality, digitalization, is having a significant impact on many traditional markets. Education has long been committed to traditional values. However, in recent years, new players have appeared on the educational services market, occupying segments of university activities. In the face of the Covid-19 pandemic, competition between educational startups and universities has intensified. But educational startups are looking to generate profits and increase the number of users of their services. Higher requirements are imposed on universities. They perform social functions, implement the tasks of state policy for the development of high-tech sectors of the economy and industry. Differences in legal status, in the field of activity and conditions of its implementation create significant difficulties for universities. This circumstance must be taken into account when developing a strategy for the development of universities.

\section{UNIVERSITIES ON THE MARKET OF EDUCATIONAL TECHNOLOGIES}

Universities in the context of the transition to a new technological reality and an increase in the level of global competition are regarded as drivers of positive changes and development. Regional Russian universities that had the status of flagship universities were considered as drivers of regional development [1]. This expectation requires universities to be at the forefront of technological change. Not only to train personnel for the changing markets of services and production, but also to initiate these changes, in fact "create" new markets.

Despite the commonality of terminology and legal status, the concept of a regional university, as well as of a flagship university, can be filled with different content depending on the positioning of a particular university, the level of technological development of the region, the presence or absence of an innovation system around the university, etc.

Accordingly, the conditions for fulfilling the role of "regional development driver" may differ significantly. At the same time, for the implementation of this function, significant transformational changes are required within the university itself. The need for such a transformation has increased significantly under the influence of two factors - the development of the EdTech educational services market and quarantine measures: established in connection with the spread of the new coronavirus infection Covid-19.

The EdTech educational services market is a combination of the latest technologies in education, aggressively advancing on traditional educational practice. New digital technologies began to be actively used in the field of organizing the educational process, interaction between teacher and student, for conducting classes in various formats and organizing research activities. These technologies have significantly pushed the market for tutoring services, especially in the field of teaching foreign languages and information technologies. Major players such as Yandex Lyceum, SberKlass, educational portal for teaching marketing, design, design and project management GeekBrains with GeekUniversity professional training programs from Mail.ru [2] with 
guaranteed employment, etc. are concentrated in this niche of educational services.

The dramatically changed competitive environment and the transition to full distance in March 2020 gives grounds to revise the university model as a driver of innovative changes in the region.

As already noted, generalizations for the subject of our study do not allow us to draw reasonable conclusions. Accordingly, it seems more effective to conduct an analysis on the example of a specific university.

\section{ANALYSIS OF THE UNIVERSITIES POSITIONING IN THE REGIONAL MARKET OF EDUCATIONAL SERVICES}

Pskov State University (PskovSU) belongs to the regional flagship universities of the North-West of Russia and occupies a leading position in the segment of higher education in the Pskov region. New educational technologies have not spared the university. PskovSU connects its future with EdTech. But the rates of technological and social changes are so high that it is not easy to find answers to the questions - what and how to teach today and now in the conditions of accelerated technological progress.

Covid-19 has removed the relevance of the discourse on the benefits of traditional or distance education. The use of distance technologies has become a reality of everyday educational practice for all universities. But distance learning has not become an obvious alternative to traditional learning formats. On the contrary, most experts lean towards the advantages of a mixed format, where social interaction and communication between participants in the educational process does not disappear.

As a new technological platform in higher education, EdTech is based on massive open online courses (MOOC), which allow organizing the educational process simultaneously for a large number of students. Students and teachers of PskovSU received their first mass experience of working with the MOOC.

PskovSU teachers have developed several online courses. The support was provided by Peter the Great St. Petersburg Polytechnic University and the North-West Regional Center of Competence in the field of online learning. Courses are hosted on the Open Education platform (https://openedu.ru/); Innovative technologies in social work (https://openedu.ru/course/spbstu/ITSW/); Web 2.0 Language programming Python (https://openedu.ru/course/spbstu/WEBPYT/) and others. The marked courses are in demand among the student audience. As of June 2020, more than seven thousand students are already engaged in them.

The pandemic situation, as the first reaction, generated shock. But the sudden collapse made it possible to objectively compare the stability of the higher education system in our country and the education systems of different countries, to test the strength of universities. The response of the Russian education system as a whole has been quite effective. The experience gained made it possible to formulate some conclusions.

There was a rethinking of the concept of online learning. It's not just about having electronic content. Not just educators with digital competencies. The university should create a system of technical support and the necessary infrastructure. It is necessary to promptly resolve issues that arise among students and teachers. This requires experience and a sustainable digital system both at the university and throughout the country.

During the pandemic, more than two thousand students received free access to ninety online courses. Both students and teachers were able to feel the attractiveness of the new formats, to understand that the process of mastering the MEP is based on the latest technologies. The online learning format provides additional opportunities for communication, social adaptation in the online environment. At the same time, online learning requires deep immersion in the material.

Organization of high-quality and systematic work in an online environment takes time. In conditions of fierce competition in the educational services market, time is becoming the most scarce resource for universities, especially regional ones. At the same time, higher education is characterized by long-term processes associated with the formation of new professions, the introduction of new educational technologies. The training of specialists in many areas takes a long period of time. Commercial players, by contrast, are implementing most educational startups in the short-term training space.

The formation of new educational practices is associated with changes in approaches to managing the educational process. The Learning Management System (LMS) provides two basic functions: 1) construction and management of the individual educational trajectory of the student; 2) assessment and certification of educational results in a single coordinate system. The first educational startups in the world appeared exactly as LMS projects and received the most funding [3]. The capabilities of LMS systems open the way for the transition to a new paradigm of education. From the logic of choosing an educational program, there is a transition to the logic of managing the formation of a set of competencies. This circumstance is one of the basic reasons for increasing competition in the educational services market. The need for competencies forces us to turn to those who are able to do it faster, better and cheaper.

Universities are obliged to realize not only their place in the new reality. They must transform to a new quality of services provided and to a new management system. As a result, there should be a qualitative leap in changing the "institutional core" of education - from managing an educational institution to managing an educational trajectory. It should be borne in mind that in different universities and states, the level of technological development and digital infrastructure differ greatly. This circumstance increases the digital divide. Therefore, regional universities need to strive to develop an innovation ecosystem in the region, to cooperate with other EdTech entities.

The creation of cooperative ties and the organization of network interaction are the main elements of changing the positioning of a regional university.

The result of using the strategizing method in the study of the innovative potential of regional universities was the identification of risks that have a significant impact on the problems in the organizational and legal management of the 
implementation of EdTech in the educational space of the region.

The main risk is the presence of systemic constraints (personnel, technological, innovative) at regional universities. In the event of an increase in the level of systemic risks, it is necessary either to quickly change the concept of positioning the university in the educational services market (if any), or to design an educational business model, or to establish a special status of a trans-participant in the educational market at the regional level.

We offer a classification of factors of "qualitative changes in education" [4], relevant for the Pskov region.

External factors: volatility in the formation of the educational services market (the short-term project-MOOC [5] did not provide dominant incomes), renewal of professions in the labor market, personification of the competence framework, high demand for digital competencies; a significant share of the demand for online course development (totaling 161\%) [6]; prevalence of persons of retirement age by $5 \%$.

Mesofactors: regional specialization of the nonmanufacturing sector, the sectoral advantage of construction, tourism, transport logistics, a transit position for mutual migration flows and their networkization, competitiveness at the price of professional potential when launching point and low-cost educational programs, including those designed to form an individual set of competencies.

Internal factors for a regional university:

- comprehensive, including compensatory adaptation of educational potential (does not imply a complete replacement, or only rejuvenation of personnel, but a gradual renewal of professional competencies and labor thinking);

- restructuring and redistribution of available resources when combining IT labor and human labor, subject to minimizing time costs;

- taking into account the target audience depending on the growth of foreign students (Tajikistan, Uzbekistan, Turkmenistan, the Baltic countries) by $10 \%$ as of 2020 [7];

- limited autonomy in the development of alternative road maps for the development of the university for short-term periods.

In general, the list of these factors is not exhaustive. But it reflects the crisis and strategic points of response.

According to the relative data of the Higher School of Economics, as a result of the analysis of the situation, the EdTech market is characterized by the following conditions:

- the share of the commercial sector $(19.2 \%$, of which $8.9 \%$ in the field of higher education),

- the share of online education (up to $2.6 \%$ of which $1.8 \%$ in the field of higher education), gross income (about RUB 15 billion)

These indicators confirm the low level of penetration potential of EdTech in Russia. Moreover, according to
M.V. Pashkovskaya [8], Russia lags behind the main consumers of IT resources by 15-20 years in the field of introducing digital resources when launching startups as "industry accelerators" of higher education, despite the significant number of leading Russian companies supplying IT products. Out of 35 participants with a total volume (RUB 9.5 trillion), only 7 leading companies with a volume (RUB 1.5 trillion or $16.24 \%$ ) are implementing projects in the field of higher education [9].

\section{RESTRICTIONS AND OPPORTUNITIES OF REGIONAL UNIVERSITIES: A SYSTEM APPROACH}

The presence of a state of uncertainty and volatility of risks of organizational and technical processes in a university should establish management mechanisms based on a comprehensive, phased and systemic integration of the EdTech market elements.

Management, technological, production inertia is acutely felt at the regional level. This is reflected in the global lag in the formation of the EdTech market conjuncture and the launch of eLearning startups [10]. The following solutions could be competitive tracks:

- sales of training solutions;

- release of game mechanics solutions;

- launching simulations of business processes

- introduction of online platforms for exam preparation;

- cooperation of the business model "MOOC-platform" [11];

- outsourcing of online courses;

- educational development franchises;

- diversification of educational platforms by aggregators and services: Udemy, Degreed, SkilledUp, LRNGO (teacher-tutor marketplace), EdModo (note - the offer for Moodle decreased by 44\%).

The existing systemic problems of the subsidized development of the region (Pskov region), requiring the Eintegration of partnerships with other regions and the synchronization of such solutions when introducing digital technologies in the creation of the E-educational space, as a possible multiplier of scaling and diversification of proposals in the labor market, cannot be disregarded. An example is a network-based approach to organizing online learning.

It is necessary to distinguish between the places of implementation of educational functionality - "the market of educational services" or "education system". Basic rules are established for the education system at the legislative level. It is in this system that traditional subjects of educational activity function. The educational services market responds quickly to demand and is not subject to many regulatory restrictions. Universities are "squeezed" by educational standards and other requirements of the regulator. The characteristic features of the regulation of educational activities are legal inertia and inertia. The need for changes is not taken into account, it takes a lot of time to move to new mechanisms and tools. Back in 2018, experts of the forum on digital transformation issues came to the conclusion that legal regulators [12] would not 
keep pace with rapid changes. This creates a situation of uncertainty. Accordingly, for the education sector, not only the issue of revising regulatory rules, but also the possibility of implementing common law norms has become a topical discussion.

It is necessary to distinguish between the concepts of "educational activity" and "educational services". They differ in their legal and economic nature, functionality, taking into account the status of the subject of educational activity. The following types of educational organizations can be distinguished:

- Non-governmental organizations. They independently develop their strategy for the educational services market. They operate within the framework of the concept of legal regulation of civil law relations for the provision of educational services. The advantage of business entities is expressed by the diversification of educational services. The share of costs has been reduced due to savings in training time, automation and availability of educational processes with a focus on SoftSkills. These entities actively use educational venture and risk.

- Public sector entities. They operate within the framework of the administrative regulations of the state founder. The main task is to develop educational relations within the framework of the national educational policy. The disadvantages are associated with organizational and legal risks (educational standards), significant time costs for educational investments. However, the advantage is preserved due to the academic and scientific nature of educational processes as a strategic criterion for the quality of education.

In our opinion, in conditions of restrictions and a post-like stage for a regional university, the main prospects of EdTech lie in the removal of inertial and reverse processes, expressed in the gravitation to traditional thinking and offline. Requires a transition to educational management, monitoring and auditing of educational needs and outcomes [13]. Educational functionality can be diversified by design, marketing, delivery and implementation of educational developments, as well as the synchronization of educational and IT technologies in the creation of adapted algorithms, terminologies and joint developments.

Positive consequences for the regional university will be caused by the transition to the principles of EdTech humanity, adaptability, consistency and complexity in changing educational approaches and methods with the transition to personification, online courses of point skills and abilities, motivational learning. At the same time, separately asynchronous learning demonstrates an insufficient effect of educational results even with the integration of IT resources, which requires external educational management over the learning object as part of a set of measures for adapting educational approaches, methods, educational developments and building an educational EdTech model, taking into account regional risks and university opportunities.

\section{CONCLUSION}

In general, taking into account the specified classification of factors, groups of risks and prospects, it seems that a regional university can become participants in the EdTech market. Forms of possible participation:

- a driver of the quality of IT educational processes;

- a leading provider of educational content;

- architect of Edu business models;

- the leading translator of new professions and competence framework;

- integrator of educational processes and IT resources;

- archiver and translator of unique educational experience;

- an institutional activator for the launch of cluster initiatives support centers, regional competence centers, interdisciplinary project centers.

The integration of service platforms and other IT products is directly dependent on the attraction of technological flows, the transformation of traditional participants (educational institutions) of the educational system when launching educational cooperation on the principle of participation (not collaboration). A good example is the creation of a multifunctional educational center in Irkutsk (Sirius), where all resources (technological, investment, educational and managerial, etc.) are combined and integrated.

The drivers of the service [14] for the promotion of educational services by a regional university may be the following tracks:

- creation of online templates of educational content for each academic discipline using service platforms,

- preparation of projects of online courses to order;

- development of methodological support synchronization;

- automation of marketing projects monitoring for SoftSkills [15], promotion and sales of courses using CRM, 1C-Bitrics (on the analysis of consumer expectations).

For example, the following projects have been launched in world practice [16]:

- GetCourse - a platform for creating and promoting courses, including branding services, creating a CRM system, accepting payments;

- Group Kaxoot - online platform contains ready-made templates for educational content, messenger and file sharing;

- Kira Talent is a "resume and portfolio analysis system" that evaluates soft-educational results;

- Kidaptive - "online platform for automating educational routine (checking attendance, evaluating completed assignments)";

- Hollihop - CRM-system of educational management, monitoring, accounting and accumulation of a data bank of Edu-service recipients. 
Thus, regional universities need a clear strategy for entering the EdTech market, creating mechanisms for integrating traditional educational activities with new digital technologies.

\section{References}

[1] Olga Vasileva: flagship universities - drivers of regional development [Olga Vasileva: opornye universitety - draivery razvitiya regionov], 4 science, 2017. (In Russ.). Retrieved from https://4science.ru/articles/Olga-Vasileva-opornie-universiteti-draiverirazvitiya-regionov

[2] GeekBrains - educational portal, 2020. (In Russ.). Retrieved from https://geekbrains.ru/courses?utm source $=$ cityads\&utm medium $=c p a \&$ utm_campaign $=$ cityads\&utm_content $=$ courses\&utm_term $=30 \% 2 F 09 \% 2$ F2017\&partner_id=cityads\&click_id=7IbZ1SCjtLZebp8\&sub_id=4vTA

[3] D.S. Konanchuk, "EdTech: new technological platform in education", University Management: Practice and Analysis, 2013, vol. 5(87), pp. 6573. (In Russ.)

[4] V.M. Soloviev, "EDTECH in Russia", in Proceedings of X RSPC on Information Technologies in Education [Informatsionnye tekhnologii $\mathrm{V}$ obrazovanii], 2018, pp. 338-341. (In Russ.).

[5] E.A. Konyushkin, "Development of mass open online course, the possibility of implementation in Russian education", Quality. Innovation. Education, 2014, vol. 6(109), pp. 15-18. (In Russ.).

[6] Moscow City Innovation Agency. EdTech: perspective directions of development [EdTech: perspektivnye napravleniya razvitiya], 2019. (In Russ.). Retrieved from https://innoagency.ru/files/EdTech_AIM_2019.pdf

[7] Pskov State University: Requirements for the internationalization of higher education [Trebovaniya $\mathrm{k}$ internatsionalizatsii vysshego obrazovaniya], 2020. (In Russ.). Retrieved from https://pskgu.ru/page/ebf4c837-77ce-4ab9-9787-af8fccfe1e61

[8] M.V. Pashkovskaya, "Prospects of development of startup in higher education", Azimuth of scientific research: economics and administration, 2020, vol. 9(1-30), pp. 261-263. (In Russ.).

[9] 35 largest EdTech-companies in Russia: rating RBC, 2019. (In Russ.). Retrieved from https://trends.rbc.ru/trends/education/ 5d68e8fb9a7947360f1e2e52

[10] V.I. Petrishche, "Online courses in the education system", in Proceedings of RSMC on Best Practices "Challenge by Number", 2020, pp. 50-54. (In Russ.).

[11] A. Watted, and M. Barak, "Motivating factors of MOOC completers: Comparing between university-affiliated students and general participants", Internet and Higher Education, 2018, vol. 37, pp.11-20.

[12] T.O. Sundukova, and G.V. Vanykina, "EDTECH: Social and legal aspects in education", Problems of scientific thought, 2019, vol. 8(3), pp. 44-47. (In Germ.).

[13] Alternative Education: EdTech Development Trends, 2019. (In Russ.). Retrieved from https://www.forbes.ru/partnerskie-materialy/373917alternativnoe-obrazovanie-trendy-razvitiya-edtech

[14] J.A. Chekulaeva, "Modern technologies in professional development of teaching personnel: basic trends", Scientific Notes of IME RAE, 2020, vol. 1(73), pp. 41-45. (In Russ.).

[15] H. Tseng, X. Yi, and Hs.-T. Yeh, "Learning-related soft skills among online business students in higher education: Grade level and managerial role differences in self-regulation, motivation, and social skill", Computers in Human Behavior, 2019, vol. 95, pp. 179-186.

[16] J.E. Hughes, "Learning Across Boundaries: Educator and Startup Involvement in the Educational Technology Innovation Ecosystem", Contemporary Issues in Technology and Teacher Education, 2019, vol. 19(1), pp. 62-96. 